\title{
The molecular processes of urea hydrolysis in relation to ammonia emissions from agriculture
}

\author{
Jens Jakob Sigurdarson $(\mathbb{D} \cdot$ Simon Svane $\mathbb{D} \cdot$ Henrik Karring $\mathbb{1}$
}

Published online: 17 April 2018

(C) The Author(s) 2018

\begin{abstract}
Ammonia emissions from the agricultural sector give rise to numerous environmental and societal concerns and represent an economic challenge in crop farming, causing a loss of fertilizer nitrogen. Ammonia emissions from agriculture originate from manure slurry (livestock housing, storage, and fertilization of fields) as well as urea-based mineral fertilizers. Consequently, political attention has been given to ammonia volatilization, and regulations of ammonia emissions have been implemented in several countries. The molecular cause of the emission is the enzyme urease, which catalyzes the hydrolysis of urea to ammonia and carbonic acid. Urease is present in many different organisms, encompassing bacteria, fungi, and plants. In agriculture, microorganisms found in animal fecal matter and soil are responsible for urea hydrolysis. One strategy to reduce ammonia emissions is the application of urease inhibitors as additives to urea-based synthetic fertilizers and manure slurry to block the formation of ammonia. However, treatment of the manure slurry with urease inhibitors is associated with increased livestock production costs and has not yet been commercialized. Thus, development of novel, environmentally friendly and cost-effective technologies for ammonia emission
\end{abstract}

J. J. Sigurdarson · S. Svane · H. Karring $(\bowtie)$

Department of Chemical Engineering, Biotechnology and Environmental Technology, University of Southern Denmark, Campusvej 55, 5230 Odense, Denmark

e-mail: hka@kbm.sdu.dk mitigation is important. This mini-review describes the challenges associated with the volatilization of ammonia in agriculture and provides an overview of the molecular processes of urea hydrolysis and ammonia emissions. Different technologies and strategies to reduce ammonia emissions are described with a special focus on the use of urease inhibitors. The mechanisms of action and efficiency of the most important urease inhibitors in relation to agriculture will be briefly discussed.

Keywords Environment - Livestock · Fertilizer · Manure slurry $\cdot$ Urease $\cdot$ Inhibition

\section{Introduction}

Nitrogen $(\mathrm{N})$ is an essential macronutrient for all organisms and is needed in the formation of proteins, DNA and other important biological molecules. In agriculture, N-containing fertilizers are regularly applied to fields to facilitate the growth of plants and maximize crop yield. The amount of applied $\mathrm{N}$ in agriculture surpasses both phosphorus $(\mathrm{P})$ and potassium $(\mathrm{K})$, which are two other essential nutrients. Nitrogen fertilizers generally fall into one of two categories, organic fertilizers and synthetic (or inorganic) fertilizers. The two types of fertilizers differ in the form and/or source of the nitrogen they contain. 
Organic fertilizers are mostly waste from animal production (manure slurry and solid manure) or derived from composted dead vegetable material. In animal manure slurry (mixture of feces and urine), $\mathrm{N}$ primarily originates from urinary urea $\left(\mathrm{CH}_{4} \mathrm{~N}_{2} \mathrm{O}\right.$, alternatively written as $\mathrm{NH}_{2}(\mathrm{CO}) \mathrm{NH}_{2}$ or $\mathrm{CO}\left(\mathrm{NH}_{2}\right)_{2}$; Fig. 1). Urea concentrations in animal urine are influenced by several factors, such as the diet and hydration level of the animals. Some reported urea-N concentrations are $4.70 \pm 0.85 \mathrm{~g} \mathrm{~N} / 1 \quad(335.6 \pm$ $60.7 \mathrm{mM}$ ) (Canh et al. 1997) and $2.79 \pm 0.07 \mathrm{~g} \mathrm{~N} / 1$ $(198.4 \pm 5.0 \mathrm{mM}$ ) (Dai and Karring 2014) in the urine from pigs and $2.14 \pm 0.15 \mathrm{~g} \mathrm{~N} / 1$ (152.7 \pm $1.1 \mathrm{mM}$ ) (Dai and Karring 2014) and 2.15-10.68 g N/1 (153.2-762.6 mM) (Edouard et al. 2016) in the urine from cattle. Synthetic/inorganic N fertilizers are synthetically produced (e.g., containing synthetic urea or ammonium nitrate, $\mathrm{NH}_{4} \mathrm{NO}_{3}$ ). In 2014, the global demand for synthetic nitrogen fertilizer was 113.1 million tonnes, and the demand is expected to increase to 119.4 million tonnes in 2018 (FAO 2015). Urea is the most commonly used $\mathrm{N}$-source in synthetic fertilizers globally, and in 2014, it represented $55 \%$ of the synthetic/inorganic fertilizer market (Heffer and Prud'homme 2015).

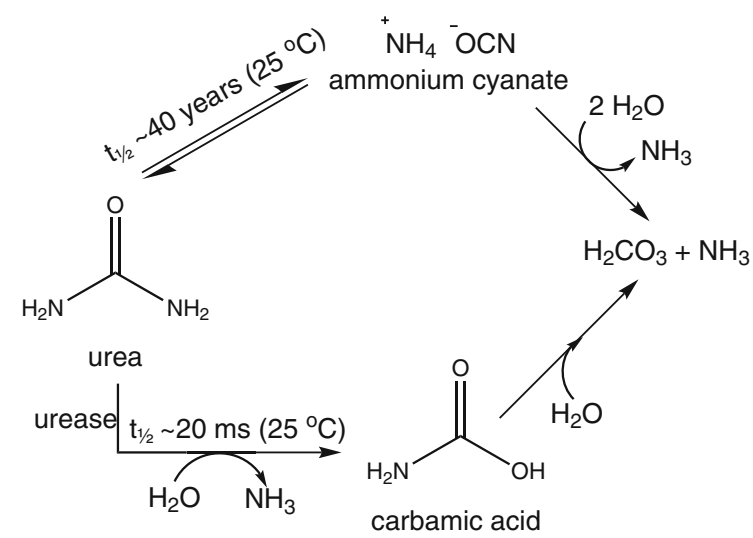

Fig. 1 Urea decomposition pathways. The lower pathway illustrates the biologically relevant and rapid urease-catalyzed hydrolysis of urea. The upper pathway shows the very slow, uncatalyzed elimination reaction of urea in aqueous solution. The last step in both pathways is very fast and occurs spontaneously. The result of both degradation pathways is the formation of two molecules of ammonia $\left(\mathrm{NH}_{3}\right)$ and one carbonic acid molecule $\left(\mathrm{H}_{2} \mathrm{CO}_{3}\right)$ from one molecule of urea

\section{Enzymatic degradation of urea}

Urea is a very stable molecule with a half-life $\left(t_{1 / 2}\right)$ of approximately 40 years at $25^{\circ} \mathrm{C}$, and therefore, it is not spontaneously hydrolyzed (degraded) in solution (Callahan et al. 2005; Shaw and Bordeaux 1955). However, the enzyme urease (EC 3.5.1.5) catalyzes a reaction in which one molecule of urea is hydrolyzed to form two molecules of ammonia $\left(\mathrm{NH}_{3}\right)$ and one carbonic acid $\left(\mathrm{H}_{2} \mathrm{CO}_{3}\right)$ via the formation of carbamic acid $\left(\mathrm{H}_{3} \mathrm{CNO}_{2}\right)$ according to the reaction shown in Fig. 1. Thus, urease must be present for the hydrolysis of urea to occur at a significant and relevant rate (Krajewska 2009; Mobley and Hausinger 1989; Mobley et al. 1995). The half-time of the urease-catalyzed reaction is only $20 \mathrm{~ms}$ at $25^{\circ} \mathrm{C}$, making urease one of the most proficient enzymes known to date (Callahan et al. 2005; Estiu and Merz 2004; Laidler and Hoare 1950).

\section{Ammonia emission from livestock production and fertilized fields}

In agriculture, the formation of ammonia from urea occurs primarily in livestock buildings, manure slurry tanks, and when inorganic urea-based fertilizers are applied to fields (Groot Koerkamp et al. 1998; Misselbrook et al. 2016; Sommer and Hutchings 2001). It has been estimated that $80.6 \%$ (39 Teragram (Tg) $\mathrm{NH}_{3}-\mathrm{N}$ ) of global $\mathrm{NH}_{3}$ emissions in 2005 came from the agricultural sector with $34.1 \%$ of the emissions arising from manure management (Behera et al. 2013). Total anthropogenic ammonia emissions increased to $65 \mathrm{Tg} \mathrm{NH}_{3}-\mathrm{N}$ per year by 2008. In contrast total reactive nitrogen contributions from human sources were around $220 \mathrm{Tg} \mathrm{N}$ per year in 2010, which is roughly equal to the total reactive nitrogen fixed by biological sources (Fowler et al. 2015).

A previous study has shown that the hydrolysis of urea in animal manure slurry is complete within approximately $20 \mathrm{~h}$ after the urine and feces are mixed, and, therefore most of the urine-derived urea is normally converted into ammonia before the manure slurry is applied to the fields (Dai and Karring 2014). As ammonia is a volatile compound, it is emitted as a gas from the manure slurry and pollutes the atmosphere and surrounding environment. This means that 
the agriculture and more specifically livestock management and crop fertilizer application are the largest contributors to anthropogenic ammonia emission (Erisman et al. 2007; Fangmeier et al. 1994). The rate of ammonia emission from the manure slurry and fertilized fields depends on several factors, such as temperature, $\mathrm{pH}$, storage type, and handling techniques (Hutchings et al. 2001). In solution (e.g., manure slurry or wet soil), ammonia is in equilibrium with its protonated form, ammonium ion $\left(\mathrm{NH}_{4}{ }^{+}\right)$, which is not volatile (Fig. 2).

The point of equilibrium between $\mathrm{NH}_{3}$ and $\mathrm{NH}_{4}{ }^{+}$in solution depends on the $\mathrm{pH}$ of the solution. At neutral or basic $\mathrm{pH}(\mathrm{pH}>7), \mathrm{NH}_{3}$ will be formed and is lost through emission (app. 50\% on $\mathrm{NH}_{3}$-form at $\mathrm{pH}$ 9.3). At acidic $\mathrm{pH}(\mathrm{pH}<7)$, most of the $\mathrm{NH}_{3}$ will be converted to cationic ammonium that cannot evaporate (app. 99\% on $\mathrm{NH}_{4}{ }^{+}$-form at $\mathrm{pH} 5.5$ ). The $\mathrm{pH}$ dependent ratios of $\mathrm{NH}_{3}$ and $\mathrm{NH}_{4}^{+}$, known as chemical speciation, have been calculated using software developed by Alderighi et al. (1999).

Ammonium tends to be less subjected to leaching from the soil compared to other $\mathrm{N}$-containing fertilizers, such as nitrate $\left(\mathrm{NO}_{3}{ }^{-}\right)$, as ammonium ions can bind to negatively charged soil colloids, thereby replacing other cations, e.g., $\mathrm{Ca}^{2+}$ and $\mathrm{Mg}^{2+}$ (Pearson and Stewart 1993).

\section{The soil microbiome and the $\mathrm{N}$-cycle}

The processes that constitute the $\mathrm{N}$-cycle in soil are driven by bacteria, archaea, fungi, and plants (Myrold 2003). Generally, the microbial community in soil has been found to depend on the soil type, plant life and other factors such as climate (Girvan et al. 2003; Prober et al. 2015; Tedersoo et al. 2014). However, one recent study compared metagenomic data from various soil types, environments and climates, and found that microbial genera encoding for specific $\mathrm{N}$-cycling processes were largely similar across

$$
\begin{aligned}
& \text { (a) } \mathrm{NH}_{3} \text { (aq) }+\mathrm{H}^{+} \text {(aq) } \rightleftharpoons \mathrm{NH}_{4}^{+}(\mathrm{aq}) \\
& \text { (b) } \mathrm{NH}_{3} \text { (aq) } \rightleftharpoons \mathrm{NH}_{3}(\mathrm{~g})
\end{aligned}
$$

Fig. 2 Equilibria involved in ammonia emission (a) Solution equilibrium between water-dissolved (aq) ammonia $\left(\mathrm{NH}_{3}\right)$ and ammonium ions $\left(\mathrm{NH}_{4}{ }^{+}\right)$. (b) Equilibrium between $\mathrm{NH}_{3}$ in solution (aq) and in the gas phase (g) habitats (Nelson et al. 2016). This indicates that specific genera may be responsible for specific N-cycling processes across the globe. Additionally, the study found that especially the nitrification process seems to be carried out only by a narrow range of genera, while all bacteria and archaea can perform ammonia assimilation.

\section{Deposition of ammonia in the environment and the effects on ecosystems}

Volatilized ammonia is deposited in the environment relatively quickly, resulting in high ammonia concentrations predominantly close to the source of emission (Fangmeier et al. 1994; Pearson and Stewart 1993; van der Eerden et al. 1998). High amounts of ammonia deposition can affect both terrestrial plants and aquatic ecosystems (Fig. 3a). Deposited ammonia can be oxidized to various nitrogen compounds via the $\mathrm{N}$-cycle (Fig. 3b). With a few exceptions, the N-cycle is nearly identical in aquatic and terrestrial ecosystems (Arrigo 2005; Krupa 2003). When ammonia is deposited, it can either be converted to nitrite $\left(\mathrm{NO}_{2}{ }^{-}\right)$and then nitrate $\left(\mathrm{NO}_{3}{ }^{-}\right)$through the nitrification process (e.g. by Nitrosomonas spp. and Nitrosococcus spp.) or be absorbed and assimilated by plants or microorganisms (Fig. 3b) (Sharma and Ahlert 1977). However, both processes result in protons being released, thereby decreasing the $\mathrm{pH}$ of the local environment (Pearson and Stewart 1993; Vitousek et al. 1997). This decrease in $\mathrm{pH}$ has been shown to reduce the viability of the microorganisms responsible for nitrification, which consequently prevents the transformation of ammonia to nitrate (Camargo and Alonso 2006; Dancer et al. 1973). Furthermore, if more ammonia is present than the nearby plants can assimilate, it can cause disruption of the plant cell membrane and even leaf etching and necrosis (van der Eerden 1982). Additionally, unfertilized plant ecosystems often have a relatively closed cycling of nitrogen, meaning that little nitrogen leaves or enters the system (Fenn et al. 1998). Such ecosystems, especially those that have adjusted to nitrogen-sparse conditions (e.g., heaths, meadows, and high moors), are vulnerable to the external supply of nitrogen (Krupa 2003). Plant species that are specialized to grow in nutrient-poor environments are easily out-competed by non-specialized species when external nutrients, such as 


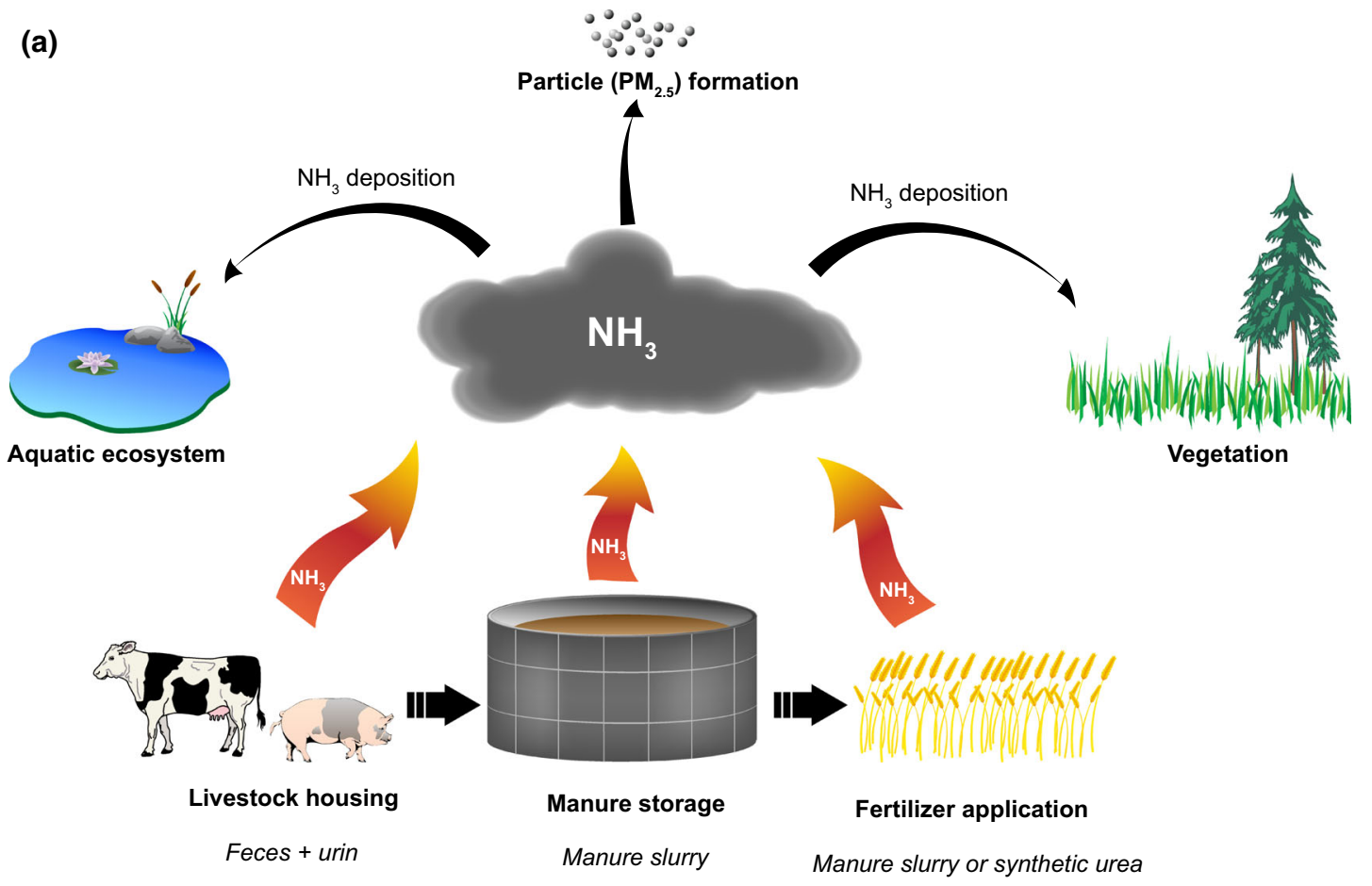

(b)

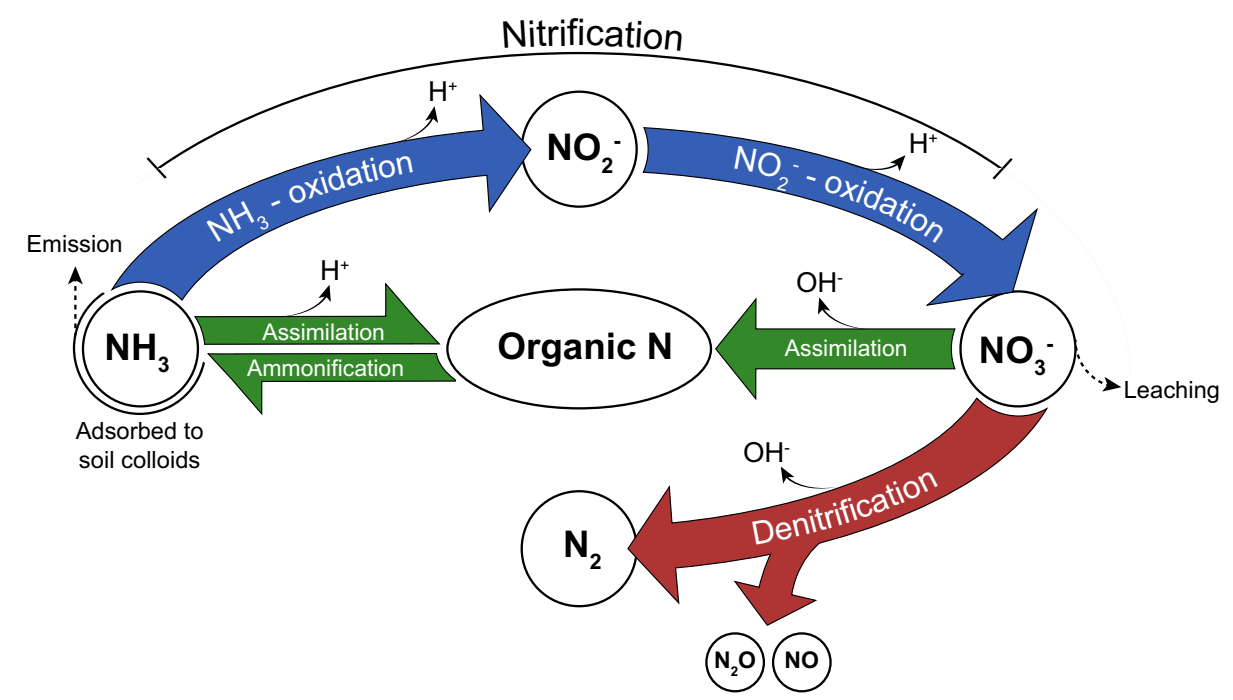


4Fig. 3 The environmental consequences of ammonia emission from agriculture and conversion of ammonia in the nitrogen cycle. a Emissions of ammonia in agriculture originate primarily from livestock housing (more specifically the feces and urine produced by livestock), storage of the manure slurry, and application of manure slurry or synthetic urea-based or ammonium fertilizers to crops. The emitted ammonia can then be deposited in nearby environments, causing harm to aquatic ecosystems and vegetation. Furthermore, emitted ammonia can increase the formation of atmospheric particulate matter $\left(\mathrm{PM}_{2.5}\right)$. b Simplified depiction of the nitrogen cycle with a focus on the processes that are relevant for ammonia emission and deposition. The blue arrows (upper pathway) indicate processes that require oxygen. During the nitrification process ammonia $\left(\mathrm{NH}_{3}\right)$ is first oxidized to nitrite $\left(\mathrm{NO}_{2}{ }^{-}\right)$which is further oxidized to nitrate $\left(\mathrm{NO}_{3}{ }^{-}\right)$by different soil microorganisms. The green arrows (middle pathways) indicate processes that occur in both the presence and absence of oxygen. Ammonia and nitrate can be assimilated by plants or microorganisms to form $\mathrm{N}$-containing organic matter, When organic $\mathrm{N}$ is decomposed by microorganisms it is converted into ammonium $\left(\mathrm{NH}_{4}{ }^{+}\right)$and ammonia in the ammonification process. The red arrow (lower pathway) illustrates the denitrification process that occurs when oxygen is not present. During denitrification $\mathrm{NO}_{3}{ }^{-}$is reduced in several steps forming nitric oxide (NO), nitrous oxide $\left(\mathrm{N}_{2} \mathrm{O}\right)$ and finally resulting in molecular nitrogen $\left(\mathrm{N}_{2}\right)$. The increase or decrease in $\mathrm{pH}$ from a process is shown as giving off $\mathrm{OH}^{-}$( $\mathrm{pH}$ increase) or $\mathrm{H}^{+}$( $\mathrm{pH}$ decrease)

ammonia, are supplied (Aerts et al. 1990). It has been estimated that emissions of $\mathrm{NO}_{\mathrm{x}}$ gasses (nitrogen oxides) and ammonia have led to a $10 \%$ reduction in forest biodiversity in Europe alone (Sutton et al. 2011). A similar effect can be observed in aquatic ecosystems where the anthropogenic supply of nitrogen can stimulate the proliferation of primary producers (autotrophic organisms), such as phytoplankton, benthic algae and macrophytes, resulting in eutrophication (Fig. 3) (Camargo and Alonso 2006; Smith 2003). In aquatic ecosystems and waterlogged soils, the anoxic conditions (following from eutrophication) can result in increased denitrification of nitrate and nitrite (Fig. 3b). One of the products from denitrification is nitrous oxide $\left(\mathrm{N}_{2} \mathrm{O}\right)$, which is a potent greenhouse gas (Vitousek et al. 1997). In the atmosphere ammonia can react with sulfuric acid $\left(\mathrm{H}_{2} \mathrm{SO}_{4}\right)$ or nitric acid $\left(\mathrm{HNO}_{3}\right)$ to form ammonium sulfate $\left(\left(\mathrm{NH}_{4}\right)_{2} \mathrm{SO}_{4}\right)$ or ammonium nitrate $\left(\mathrm{NH}_{4} \mathrm{NO}_{3}\right)$ respectively, which make up a large part of fine particles in the air known as $\mathrm{PM}_{2.5}$ (particle matter with a diameter of $2.5 \mu \mathrm{m}$ or less) (Anderson et al. 2003). One study estimated that $5-11 \%$ of the total $\mathrm{PM}_{2.5}$ concentration in the United States may be attributable to ammonia emission from livestock alone (Fig. 3a) (Hristov 2011). Several studies have found that $\mathrm{PM}_{2.5}$ may deposit in the lungs, causing oxidative stress and possibly leading to increased morbidity (Riva et al. 2011; Sorensen et al. 2003). However, the toxicity of $\mathrm{PM}_{2.5}$ seems to largely depend on the specific composition (Schlesinger 2007). Furthermore, by acting as cloud condensation nuclei, the particles can increase formation and lifetime of clouds (Aneja et al. 2009). From the perspective of the farmers, the emission of ammonia from both organic and inorganic fertilizers results in a loss of valuable nitrogen, forcing the farmer to over-fertilize fields to obtain the maximum crop yield or accept less optimal production in countries with restrictions and regulations on fertilizer use. Economically about $75 \%$ of the total costs related to damage to the environment and to human health caused by emission of reactive nitrogen species can be attributed to emissions of ammonia from agriculture and $\mathrm{NO}_{\mathrm{x}}$ from combustion processes (Sutton et al. 2011).

\section{International regulations to reduce ammonia emission}

Because of the environmental and societal challenges associated with ammonia volatilization, international goals and regulations have been set to reduce the emission of anthropogenic ammonia. In 1999, the European Union (EU) Member States and the Central and Eastern European countries, along with the United States and Canada, agreed on the Gothenburg Protocol (UNECE 1999), which set out to limit the emissions of several pollutants, including ammonia, by 2010 . This protocol has formed the basis for the European Union National Emission Ceilings (NEC) Directive 2001/81/ EC (European Parliament 2001). The purpose of this directive is to transpose the reduction commitments from the Gothenburg Protocol into EU law and make binding emission ceilings for individual member states. In 2012, the Gothenburg Protocol was revised to include commitments to further the emission reductions by the year 2020. In 2016, these commitments concerning the EU member states were incorporated into the NEC Directive 2016/2284/EC (European Parliament 2016), which also includes further national reduction commitments by 2030 based on the Clean Air Program for Europe. The 
NEC Directive 2016/2284/EC commits the EU member states to reducing the overall emissions of ammonia from the EU by $19 \%$ (relative to 2005 levels) before 2030. This means that Denmark and Germany have committed to reducing their respective ammonia emissions by 24 and $29 \%$, corresponding to a reduction in the annual emission of ammonia from 72,759 tonnes (emission in 2015) to 66,540 tonnes for Denmark and from 759,300 tonnes (emission in 2015) to 481,500 tonnes for Germany (EEA 2017). To accomplish these commitments, novel ammonia emission mitigation technologies and strategies must be implemented in intensive animal production and farming. Furthermore, since $\mathrm{N}_{2} \mathrm{O}$ and $\mathrm{NO}_{3}{ }^{-}$can be microbially produced from $\mathrm{NH}_{3}$ (Fig. 3b), an added benefit of reducing ammonia emissions is the accompanying reduction in emissions of $\mathrm{N}_{2} \mathrm{O}$ and the leaching of nitrate (Sutton et al. 2011).

\section{Urine-derived versus synthetic urea as fertilizer}

To get rid of excess nitrogen from metabolism, all mammals produce urea. In mammals, urea is produced in the liver from ammonia through several biochemical steps, called the urea cycle, and it is then released into the bloodstream. Urea and other metabolic byproducts are then extracted from the bloodstream by the kidneys before they are excreted via the urine (Hill et al. 2008). Therefore, a large amount of the nitrogen in livestock manure slurry is derived from urinary urea (Canh et al. 1997; Dai and Karring 2014; Kulling et al. 2001). Urea is also produced industrially by the Bosch-Meiser urea process (Bosch and Meiser 1922), and both urine-derived (manure slurry) and synthetically produced urea are extensively used as fertilizers. Several studies have investigated the advantages and disadvantages of each fertilizer type. In terms of the growth yield and $\mathrm{N}$ content of the crops in the year of application, synthetic urea seems to have a distinct advantage over manure slurry when used as fertilizer (Khodaei Joghan et al. 2012; Paul and Beauchamp 1993; Salomonsson et al. 1994). However, the manure slurry tends to show a positive residual effect on the crops and will supply nitrogen to the crops in the years after the application as well. Therefore, the full potential of manure slurry as a fertilizer is first reached after several years of application. In the years following field application, the residual effects of previous fertilizations will contribute to the overall available nitrogen (Bhogal et al. 2016; Gutser et al. 2005; Paul and Beauchamp 1993; Schröder et al. 2006; Whitmore and Schroder 1996). The same long-term effect is not present when applying synthetic urea fertilizers (Paul and Beauchamp 1993). Thus, it may be advantageous to combine the manure slurry and synthetic urea during the first years of application and then reduce the addition of synthetic urea in the following years. However, the co-application of urea fertilizer with manure slurry has the disadvantage that urea is rapidly converted into ammonia because of the high urease activity in animal feces, consequently resulting in increased ammonia emission (Choi et al. 2007; Matsushima et al. 2009). The ammonia emission rate from fields fertilized with manure slurry peaks within the first $24 \mathrm{~h}$ after applying the manure slurry in the field. This is probably because the volatile ammonia is already present in the manure slurry when it is applied to the field (Huijsmans et al. 2001; McGinn and Sommer 2007; Rochette et al. 2009; Salazar et al. 2014). In contrast, the ammonia emission rate from the fields applied with synthetic urea fertilizer is more variable, and the maximum rate is not reached before $48 \mathrm{~h}$ to 12 days after fertilizing the field, as urea must first be hydrolyzed by the microbial urease present in the soil (Rochette et al. 2009; Salazar et al. 2014). The cumulative emissions of ammonia from the fields applied with manure slurry compared to those applied with synthetic urea fertilizers depend very much on conditions such as the method of fertilizer application, temperature, and weather (Bussink and Oenema 1998; Rochette et al. 2009; Salazar et al. 2014). Studies indicate that the emissions of ammonia from fields fertilized with synthetic urea and manure slurry are very similar. Thus, after comparing the ammonia volatilization levels reported in 92 studies, Bouwman et al. (2002) concluded that the average ammonia emissions from the synthetic urea fertilizer and manure slurry were 21.0 and $21.2 \%$ of the applied $\mathrm{N}$ fertilizer, respectively.

\section{The enzymatic degradation of urea to ammonia by urease}

Urease has a historical role in science, as in 1926, it was the first enzyme to be crystallized (Sumner 1926). Urease is also one of only a few known nickel(Ni)- 
(a)

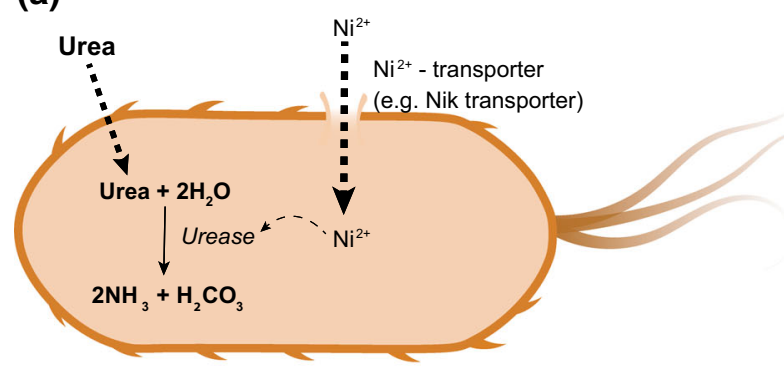

(c)

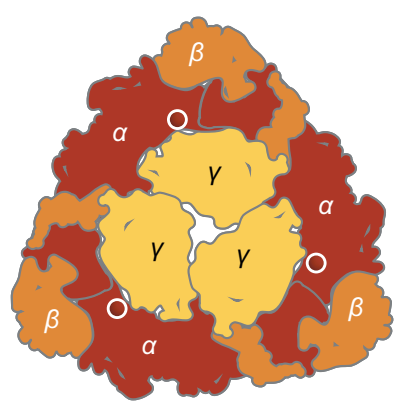

Fig. 4 Urea hydrolysis in ureolytic bacteria and urease structures. a Simplified illustration of the biochemical steps of urea hydrolysis in a ureolytic bacterium. b Illustration of the subunit structures $(\alpha, \beta$ and $\gamma)$ of urease from bacteria, fungi, and plants (Krajewska 2009). The primary structures of the different ureases are very similar, but the subunit composition of bacterial ureases is different from those of plant and fungal ureases.

containing enzymes. The two Ni-atoms in the active site of urease are expected to bind the urea molecule and facilitate the hydrolysis reaction (Benini et al. 1999; Dixon et al. 1980). They are consequently essential for the enzyme without which the reaction will not occur (Fig. 4) (Gerendas et al. 1998; Mackerras and Smith 1986; Schneider and Kaltwasser 1984). Urease is common in nature and is produced by a wide range of organisms. Urease has been found in several species of bacteria, fungi, algae, plants, and invertebrates (Bekheet and Syrett 1977; Booth and Vishniac 1987; Cook 1976; Frankenberger and Tabatabai 1982; Hanlon 1975; Sumner 1926). For many organisms, urease plays an important role in nitrogen metabolism or as a defense mechanism.

\subsection{Bacterial urease}

Urease-producing microorganisms, known as ureolytic, are found in nearly all ecosystems including soil. One study found that $17-30 \%$ of bacteria isolated (b)

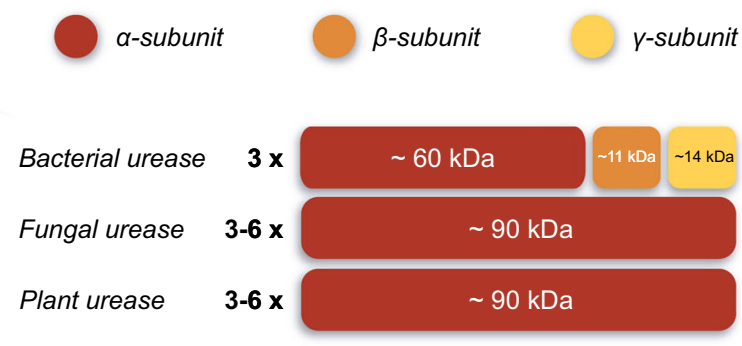

(d)

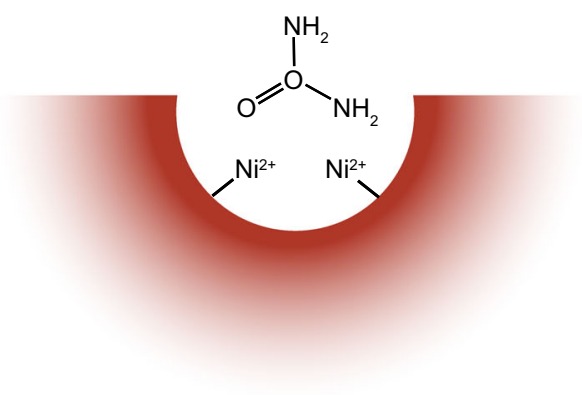

c Simplified drawing of the quaternary structure of a heterotrimeric bacterial urease [e.g. S. pasteurii (Benini et al. 1999)], showing the $3 \times 3$ subunit structure. The white rings show the approximate positions of the active sites. $\mathbf{d}$ Depiction of the active site in subunit $\alpha$ in urease, showing two nickel atoms and the positioning of urea in the active site pocket

from six soil samples produced urease (Lloyd and Sheaffe 1973). The isolated ureolytic bacteria included both anaerobes, micro-aerophiles, and aerobes, illustrating the wide range of ureolytic bacteria. The microbial community that is dominant in a specific soil is very much dependent on the soil type, the surrounding environment, and whether it has been amended with manure slurry (Girvan et al. 2003; Hamm et al. 2016). One of the most common and intensively studied ureolytic soil bacteria is Sporosarcina pasteurii (previously known as Bacillus pasteurii) (Burbank et al. 2012; Li et al. 2013), which was also the first bacteria to have its urease purified (Larson and Kallio 1954). Sporosarcina pasteurii differs from several other ureolytic bacteria in that it produces urease constitutively, while for many other bacteria the urease production is regulated in response to environmental factors such as $\mathrm{pH}$ or available nitrogen (Mobley et al. 1995). Common for almost all ureolytic bacteria is the fact that the urease is located in the cytoplasm (Fig. 4a), and is composed of three 
subunits named $\alpha, \beta$ and $\gamma$ (Fig. 4b, c) (Ha et al. 2001). For most bacteria, these three subunits are organized in so-called heterotrimers (Jabri et al. 1995) composed of three $\alpha$-subunits, three $\beta$-subunits, and three $\gamma$ subunits (Fig. 4b, c), although some bacterial ureases have been found to be organized with different stoichiometry (Schafer and Kaltwasser 1994). Even if ureases from different organisms vary in the number of subunits, the primary structure remains remarkably similar. This similarity even extends to ureases from different kingdoms. Thus, the primary structure of bacterial urease is very similar to the ureases from plants and fungi, even though plant and fungal ureases only consist of $\alpha$-subunits (Fig. 4b) (Mobley et al. 1995). The Ni-containing active sites are located in the $\alpha$-subunits for all known ureases (Fig. 4c, d).

\subsection{Plant urease}

It has long been supposed that plants mainly take up urea- $\mathrm{N}$ after it has been converted to ammonia by microbes in the soil. However, studies have found that plants possess dedicated urea transporters that either actively or passively transport urea into the plant (Dynowski et al. 2008; Liu et al. 2003a, b). Inside the plant cells, urease hydrolyzes urea into ammonia, and the plant then uses it as a nitrogen source. In plants, urease is used to hydrolyze not only the urea acquired from the environment but also the urea that is internally produced by the plant through the catabolism of arginine and purines (Munoz et al. 2006; Reinbothe and Mothes 1962; Todd and Polacco 2004). Of note, plant urease may also be involved in a defense mechanism against herbivores and microorganisms, which can explain its high abundance in seeds such as the soybean and jack bean (Goldraij et al. 2003; Meyer-Bothling and Polacco 1987; Polacco and Winkler 1984; Stebbins et al. 1991).

\subsection{Nickel, an essential co-factor of urease}

Nickel is an essential co-factor for urease activity, as two $\mathrm{Ni}^{2+}$ ions are needed in the active site where they catalyze the hydrolysis of urea. In nature, nickel is usually only present in trace amounts, and therefore, ureolytic bacteria need a high-affinity nickel transporter system to obtain the required nickel. Two major types of high-affinity nickel transporters, namely, the Nik system and the HoxN system, have been identified in bacteria. One of the best-characterized bacterial nickel transporters is the Nik system, which belongs to the ABC transporter family (Eitinger and MandrandBerthelot 2000; Wu and Mandrand-Berthelot 1986). The Nik transport system consists of five proteins, NikA-NikE, which together facilitate the transport of $\mathrm{Ni}^{2+}$ across the plasma membrane (Fig. 4a) (Navarro et al. 1993). Nickel is toxic to the cell at higher concentrations. Therefore, along with having a highaffinity transporter system, the cell avoids accumulating a toxic level of nickel by either repressing the transcription of the nickel transporter genes or by using metal resistance determinants, such as the cnr system (Silver and Phung 1996).

\subsection{Soil urease}

The term "soil urease" refers to active cell-free urease molecules immobilized in the soil and has some importance in agriculture. Studies have found that soil urease may account for as much as 50\% of the urease activity in field soils, while the remaining activity stems from intracellular microbial urease activity (Klose and Tabatabai 1999; Qin et al. 2010). Soil urease is urease that is released from dead plants and ureolytic microorganisms after cell lysis and then immobilized on clays and humic substances. It has been suggested that the immobilization of urease results in increased enzymatic stability against both temperature and proteolytic enzymes (Ciurli et al. 1996; Pettit et al. 1976; Zantua and Bremner 1977).

\section{Established technologies for ammonia emission mitigation in agriculture}

To reduce ammonia volatilization from livestock housing, stored animal manure slurry, as well as manure slurry and urea-based fertilizers applied to fields, several technologies have been tested, and some have been employed in agriculture (Table 1). The technologies applied in a specific country depends on several factors such as local policies, livestock numbers, population density, climate and amount of arable land in need of fertilization. Well-established methods in practical use include the acidification of manure slurry in livestock housing or in storage tanks before application to the field (Stevens et al. 1989) and physical barriers, such as closed or covered storage 
Table 1 Most commonly used ammonia emission mitigation strategies in agriculture

\begin{tabular}{|c|c|c|c|c|c|}
\hline Source of $\mathrm{NH}_{3}$ & Technology & $\begin{array}{l}\text { Site(s) of } \\
\text { application }\end{array}$ & $\begin{array}{l}\text { Process } \\
\text { affected }\end{array}$ & $\begin{array}{l}\mathrm{NH}_{3} \text { emission } \\
\text { reduction }(\%)\end{array}$ & References \\
\hline Manure slurry & $\begin{array}{l}\text { Urine/feces } \\
\text { segregation }\end{array}$ & Livestock housing & $\begin{array}{l}\text { Urea } \\
\text { hydrolysis }\end{array}$ & 46 & Swierstra et al. (2001) \\
\hline Manure slurry & Acidification & $\begin{array}{l}\text { Livestock } \\
\text { housing, storage, } \\
\text { field }\end{array}$ & $\begin{array}{l}\mathrm{NH}_{3} \\
\text { emission }\end{array}$ & $<95$ & $\begin{array}{l}\text { Jensen (2002), Stevens et al. } \\
\text { (1989) }\end{array}$ \\
\hline Manure slurry & $\begin{array}{l}\text { Ammonium } \\
\text { absorption }\end{array}$ & Storage, field & $\begin{array}{l}\mathrm{NH}_{3} \\
\text { emission }\end{array}$ & $71^{\mathrm{a}}, 85^{\mathrm{b}}$ & $\begin{array}{l}\text { Barrington and Moreno (1995), } \\
\text { Portejoie et al. (2003) }\end{array}$ \\
\hline Manure slurry & Cover & Storage & $\begin{array}{l}\mathrm{NH}_{3} \\
\text { emission }\end{array}$ & $>99$ & $\begin{array}{l}\text { Funk et al. (2004), Scotford and } \\
\text { Williams (2001) }\end{array}$ \\
\hline Manure slurry & $\begin{array}{l}\text { Field } \\
\text { application } \\
\text { strategies }\end{array}$ & Field & $\begin{array}{l}\mathrm{NH}_{3} \\
\text { emission }\end{array}$ & $94-97^{\mathrm{c}}, 75-87^{\mathrm{d}}$ & $\begin{array}{l}\text { Carozzi et al. (2013), Huijsmans } \\
\text { et al. (2003) }\end{array}$ \\
\hline Manure slurry & Air scrubbing & Livestock housing & $\begin{array}{l}\mathrm{NH}_{3} \\
\text { emission }\end{array}$ & $95^{\mathrm{e}}, 96^{\mathrm{f}}$ & $\begin{array}{l}\text { Chang et al. (2004), Melse and } \\
\text { Ogink (2005) }\end{array}$ \\
\hline Manure slurry & $\begin{array}{l}\text { Cooling of } \\
\text { manure }\end{array}$ & Livestock housing & $\begin{array}{l}\mathrm{NH}_{3} \\
\text { emission }\end{array}$ & $31-47$ & $\begin{array}{l}\text { Andersson (1998), Pedersen } \\
\text { (2005) }\end{array}$ \\
\hline $\begin{array}{l}\text { Urea-based mineral } \\
\text { fertilizer, manure } \\
\text { slurry }\end{array}$ & $\begin{array}{l}\text { Urease } \\
\text { inhibitors }\end{array}$ & $\begin{array}{l}\text { Livestock } \\
\text { housing, storage, } \\
\text { field }\end{array}$ & $\begin{array}{l}\text { Urea } \\
\text { hydrolysis }\end{array}$ & $24-78$ & $\begin{array}{l}\text { Forrestal et al. (2016) Li et al. } \\
\text { (2014), Suter et al. (2013) }\end{array}$ \\
\hline
\end{tabular}

For each technology, the site of application in agriculture, the process affected by the strategy (ammonia emission or urea hydrolysis) and the efficiency in reducing ammonia emission are indicated

${ }^{\mathrm{a}}$ Zeolite, ${ }^{\mathrm{b}}$ Sphagnum peat moss, ${ }^{\mathrm{c}}$ deep injection, ${ }^{\mathrm{d}}$ incorporation after surface spreading, ${ }^{\mathrm{e}}$ biological filter, ${ }^{\mathrm{f}}$ chemical (acid) filter

tanks (Funk et al. 2004; Scotford and Williams 2001). These methods rely on either physically trapping the formed $\mathrm{NH}_{3}$ or converting volatile $\mathrm{NH}_{3}$ to non-volatile $\mathrm{NH}_{4}{ }^{+}$to prevent volatilization as described above (Fig. 2). Employing closed storage tanks does not improve the indoor climate in the stables, nor does it affect $\mathrm{N}$ loss during or after field application. It will, however, limit $\mathrm{N}$ loss during the storage of the manure slurry, but if the slurry is used as fertilizer, the build-up of ammonia will be quickly lost during field application (Massey et al. 2003). Acidification of the manure slurry to approximately $\mathrm{pH} 5.5$ can be used in the stable, and therefore, this technology improves the indoor air quality but requires the transport and storage of concentrated sulfuric acid $\left(\mathrm{H}_{2} \mathrm{SO}_{4}\right)$ (Jensen 2002). Today, automated systems exist that monitor the $\mathrm{pH}$ of the manure slurry and add the acid, making this technology safer and easier for the farmer. Furthermore, acidification helps limit ammonia volatilization after the application of the manure slurry fertilizer to the field (Kai et al. 2008; ten Hoeve et al. 2016). Previous studies found a reduction in ammonia volatilization from the fields of up to $95 \%$ when the
$\mathrm{pH}$ of the manure slurry was lowered to 5.5 with sulfuric acid (Stevens et al. 1989). As an alternative to acidifying the manure slurry directly, chemical filters have been developed. These filters act as air scrubbers in livestock housing by passing the air through acidified water. The ammonia in the air is converted to ammonium ions and trapped, with reported ammonia emission reduction of up to $96 \%$ (Melse and Ogink 2005). A different type of filter, which operates on a microbiological principle, has also been developed. Here the air is passed through a membrane where certain bacteria are growing. These bacteria use the ammonia as a nitrogen source for growth, consequently reducing the ammonia emissions with up to 95\% (Chang et al. 2004). As an added bonus these filters tend to also reduce general odor from livestock housing as the bacteria can degrade many different volatile substances. Research, however, is still ongoing to ensure high stability and process control (Liu et al. 2017). In Denmark a commercially available biological filter system has been approved by the Environmental Protection Agency in 2015 as a "best available technology" (BAT) for use in pig housing. It 
is rated to reduce ammonia emissions with $88 \%$, odor with $74 \%$ and dust $\left(\mathrm{PM}_{2.5}\right)$ with $87 \%$ (Miljøstyrelsen 2015). Chemical urease inhibitors offer the potential of controlling the molecular process of ammonia production in manure slurry all the way from the livestock housing through storage and to field application. Additionally urease inhibitors are already being employed to slow down urea degradation in urea-based synthetic fertilizers. The state-of-the-art and the barriers for further implementation will be described below.

\subsection{Ammonia emission mitigation by urease inhibitors}

Chemical compounds that inhibit soil urease and the ureolytic activity of soil bacteria are currently employed to limit ammonia volatilization from ureabased synthetic fertilizers applied in the fields. Potentially, these urease inhibitors can also be added to animal manure slurry to reduce ammonia volatilization both in stables and storage tanks and after field application, spanning several areas of ammonia release (Table 1). Urease inhibitors function on a principle of disrupting the ability of urease to catalyze the hydrolysis of urea to ammonia, thereby retaining $\mathrm{N}$ on the stable and non-volatile urea form longer. While a relatively high number of urease-inhibiting compounds are known and have been studied under laboratory conditions, only a few candidates have currently been adopted for use in commercial agriculture. Some chemicals have been found to be effective against only purified urease since they are incapable of crossing bacterial membranes or are rapidly degraded in the environment. Others are too expensive, toxic, or labile to be considered for practical agricultural applications. In the following, the only urease inhibitor currently in practical use in agriculture and its analogues will be reviewed.

$\mathrm{N}$-(n-butyl)thiophosphoric triamide (NBPT, Fig. 5) is among the most effective urease inhibitors known, and it is currently marketed as a stabilizing additive for urea-based synthetic fertilizers under the trade name "Agrotain" (Artola et al. 2011; Font et al. 2008). The active inhibitory chemical species has been thought to be the oxon derivative $\mathrm{N}$-(n-butyl) phosphoric triamide (NBPTO, Fig. 5a) which has been found to display $50 \%$ inhibition at a 1000 -fold lower concentration than the parent NBPT compound (Creason et al. 1990; Font et al. 2008; Kot et al. 2001). NBPTO is slowly but spontaneously formed from NBPT under aerobic conditions. However, a recent study crystallized urease from Sporosarcina pasteurii in the presence of NBPT and found the compound involved in inhibition, under the crystallization conditions used, to be $\mathrm{N}$-(n-butyl)phosphoric diamide (NBPD, Fig. 5b). These results indicate that the $\mathrm{P}=\mathrm{S}$ group of NBPT is not converted to a $\mathrm{P}=\mathrm{O}$ group, but instead, an ammonia molecule is exchanged for a hydroxyl group (Fig. 5b) (Mazzei et al. 2017).

NBPT has been studied due to its inhibiting effect on both synthetic fertilizers and animal manure slurry. In field studies, the urease inhibitors have generally been found to exhibit good reductions in ammonia emissions. However, the results seem to be quite variable with respect to the amount of precipitation, soil type, and temperature. Recently, it has also been suggested that the soil $\mathrm{pH}$ influences the speed with
Fig. 5 Structure and conversion of urease inhibitor N-(nbutyl)thiophosphoric triamide (NBPT) to NBPTO/NBPD in solution. NBPT is spontaneously converted into either a N-(nbutyl)phosphoric triamide (NBPTO) or b N-(nbutyl)thiophosphoric diamide (NBPD)
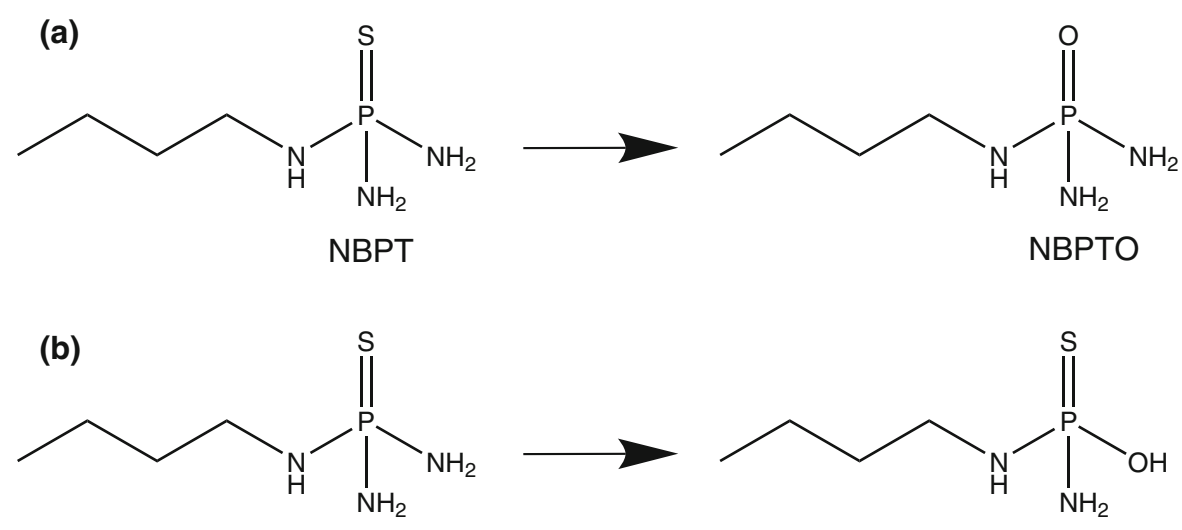

NBPT 
which the compound is degraded (Engel et al. 2015). In an early study by Cai et al. (1989) it was found that the application of NBPT to flooded rice fields did decrease the rate of urea hydrolysis but failed to increase the grain yield. However, the inhibitor was only applied once (at the time of fertilizer application), and later studies have shown that NBPT is degraded over time, making reapplication necessary (Varel 1997). Hendrickson and Douglass found that when NBPT-coated urea was used to fertilize corn, the yield increased on average by $280 \mathrm{~kg} \mathrm{ha}^{-1}$. To obtain equivalent yields using urea fertilizer without NBPT, an additional $80 \mathrm{~kg}$ fertilizer per hectare was needed (Hendrickson and Douglass 1993). In general, it is difficult to estimate to what extent crop yield is influenced by the use of urease inhibitors due to the many different factors that determine the overall ammonia emissions and N-retention, but a recent meta-analysis found that the average cumulative ammonia loss was reduced by $52 \%$ (from $31.0 \%$ of applied $\mathrm{N}$ to $14.8 \%$ ) and that the grain yield increased on average by $5.3 \%$ when synthetic urea fertilizer was amended with NBPT (Silva et al. 2017). Marchesan et al. noted that NBPT generally slowed the hydrolysis of urea to ammonia when applied to the rice crop compared to the urea fertilizer without NBPT, but the effectiveness was highly influenced by climate, type of soil, and moisture (Marchesan et al. 2013). Application of Agrotain to pure urea fertilizer or cattle urine yielded reductions in the ammonia emissions of 47 and $22 \%$, respectively (Singh et al. 2013). This study was carried out in a glass-house setup with soil samples representative of New Zealand pastures. Urea fertilizer with Agrotain has also been found to reduce the loss of ammonia by $24-70 \%$ compared to unaltered urea fertilizer when applied to ryegrass (Suter et al. 2013), and a 78\% reduction in ammonia emissions was observed when urea was applied with NBPT to the grassland (Forrestal et al. 2016).

NBPT also reduces the ammonia emissions from organic fertilizers (animal manure slurry), although only a few studies have investigated this application. Recently, it was shown that adding NBPT to dairy cattle manure slurry before application to grazing fields reduced the ammonia volatilization from 15 to $8 \%$ of the total applied N (Li et al. 2014). In addition, a Danish report from 2013 found that Agrotain sprayed directly on the surface of the cattle manure reduced ammonia volatilization by approximately $30-45 \%$
(Kai 2013). The biochemical effects of NBPT on crops are not well-understood, but a recent study found evidence that plants grown in the presence of NBPT show an altered metabolism and accumulation of urea in the plant tissue (Zanin et al. 2016), and urea-based synthetic fertilizers with NBPT decreased the plant urease activity and led to transient leaf-tip scorching in ryegrass (Watson and Miller 1996). In relation to the activity, distribution and abundance of soil microbes in soils treated with NBPT, a few studies have been carried out. A very recent paper found that while NBPT did not influence the growth or ratio of ammonia oxidizers (archaea and bacteria) in vegetable soil, soil $\mathrm{pH}$ played a prominent role (Xi et al. 2017). Another study found that application of NBPTcoated urea fertilizer reduced the decrease in soil $\mathrm{pH}$ otherwise observed on fertilization with un-amended urea, suggesting that use of NBPT may lessen the effect of urea fertilization on native soil microbial communities (Shi et al. 2017).

An earlier study concluded that the addition of urea alone or urea with NBPT did not affect the biological properties (microbial biomass $\mathrm{C}+\mathrm{N}$ content and content of arylsulfarase, acid phosphatase and alkaline phosphatase) of the test soil over a period of 1 year and 8 months (Banerjee et al. 1999). Further studies of both the long- and short-term effects of NBPT (and other urease inhibitors) on crops/plants and the soil microbiome are obviously still needed.

The potential use of another well-known and highly efficient urease inhibitor in agriculture, termed phenyl phosphorodiamidate (PPDA, Fig. 6), has been tested under laboratory conditions. However, PPDA, which has structural similarities to NBPTO (Fig. 5a), has so far seen little use in commercial agricultural production, partly due to cost.

In a study by Monem et al., no effect on grain yield or $\mathrm{N}$ loss was found when adding PPDA to wheat fields

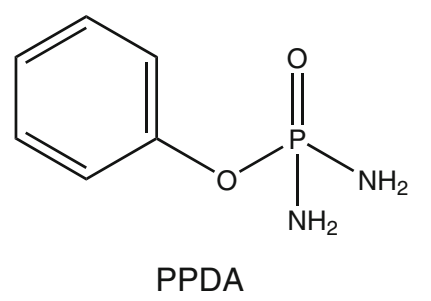

Fig. 6 Structure of urease inhibitor phenyl phosphorodiamidate (PPDA) Urease inhibitor PPDA is a diamide structurally related to the triamide NBPTO 
compared to using unmodified urea-based synthetic fertilizer (Abdel Monem et al. 2009). Earlier, in a laboratory setting, it was shown that regular addition of PPDA to cattle or pig manure slurry reduced urea hydrolysis by up to $92 \%$ over a period of 28 days (Varel 1997). Crucially, the inhibitor was added weekly as it was gradually degraded, as is also the case with NBPT. Due to the current low demand for PPDA compared to NBPT, the price is still very high and presents a significant barrier for implementing this urease inhibitor in a commercial setting. More largescale studies are needed to determine whether PPDA is a viable urease inhibitor in commercial agriculture.

\subsection{Mechanism of urease inhibition by NBPT and PPDA}

The tri- and diamides, NBPTO (Fig. 5a), NBPD (Fig. 5b) and PPDA (Fig. 6), all bind to the active site of urease where they are enzymatically hydrolyzed to form either diamidophosphoric acid (DAP, in case of NBPTO and PPDA) or monoamidothiophosphoric acid (MATP, in case of NBPD), losing a phenol group or $n$-butylamine. Diamidophosphoric acid and

(a)<smiles></smiles>

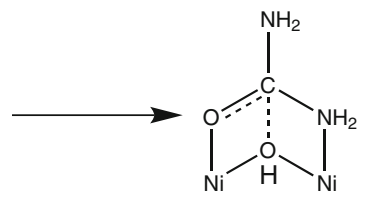

urea-urease initial binding

urea-urease transistion state

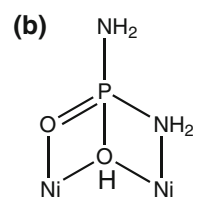

diamidophosphoric acid-urease complex

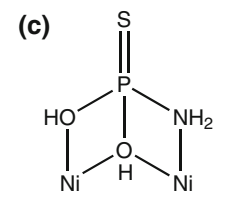

MATP-urease complex

Fig. 7 Modes of urea and urease inhibitors binding to the active site of urease. a Binding modes of the urea-urease initial complex and urea-urease transition state complex formed prior to hydrolysis. b Binding mode of diamidophosphoric acid (DAP) to the nickel active site of urease to form inhibited urease. c Binding mode of monoamidothiophosphoric acid (MATP) to the nickel active site of urease to form inhibited urease. When comparing the binding modes of urea, the urea transition state, DAP, and MATP, it is clear that binding to the urease active site occurs through one amido group and two oxygen atoms. Hydrogen bonds and amino acid residues are omitted from the illustrations monoamidothiophosphoric acid are both structural transition state analogues of urea with respect to their tetrahedral geometry, meaning that their structure is similar to the transition state complex formed during the hydrolysis of urea (Fig. 7) (Benini et al. 1999; Musiani et al. 2001; Zimmer 2000). The threedimensional structure of a urease-diamidophosphoric acid complex has been solved by X-ray diffraction using a crystallized bacterial urease complexed with PPDA (Benini et al. 1999). It was shown that the dinickel active site (two $\mathrm{Ni}$ atoms) in the $\alpha$-subunit of urease (Fig. 4) is occupied by tetrahedral DAP $\left(\left(\mathrm{NH}_{2}\right)_{2} \mathrm{OPOH}\right)$ with one $\mathrm{Ni}$ atom coordinated by an $\mathrm{O}$-atom, the other $\mathrm{Ni}$ atom coordinated by a $\mathrm{N}$-atom, and an $-\mathrm{OH}$ group symmetrically bridging the two $\mathrm{Ni}$ atoms (Fig. 7b). Recently, the crystal structure of another urease-inhibitor complex revealed that the inhibiting species was in fact MATP when the enzyme was incubated with NBPT in solution. In this case, the active site is occupied by the tetrahedral MATP $\left(\mathrm{NH}_{2} \mathrm{SP}(\mathrm{OH})_{2}\right)$. The $\mathrm{Ni}$ atoms of the urease active site are still coordinated by two oxygen atoms and an $\mathrm{N}$-atom, but the remaining atom is a double bonded $\mathrm{S}$ instead of an $-\mathrm{NH}_{2}$ group (Fig. 7c) (Mazzei et al. 2017). The presence of diamidophosphoric acid or monoamidothiophosphoric acid in the active site of urease locks the active site flap in the closed conformation, blocking the enzyme from binding and hydrolyzing urea. The initial inactivation of urease by tri- and diamide inhibitors is rapid; however, the inhibition is reversible, meaning that the enzyme will eventually regain full catalytic function.

\subsection{Other anti-ureolytic compounds}

Several other compounds are known to fully or partially inhibit urease, such as acetohydroxamic acid (Kumar and Kayastha 2010a), boric acid (Breitenbach and Hausinger 1988; Reddy and Kayastha 2006), heavy metal ions (Ambrose et al. 1951; Kumar and Kayastha 2010b) and the substrate analogues hydroxyurea and methylurea (Gale 1965; Shaw and Raval 1961). However, all have issues with anti-ureolytic effectivity, price, toxicity or chemical stability, which prevents them, at the moment, from being considered as alternatives to some of the established ammonia emission mitigation strategies in agriculture (Table 1). 


\section{Conclusions and perspectives}

Urea is extensively used as a $\mathrm{N}$-fertilizer in agriculture, and demand for it is only expected to increase in the coming years (Heffer and Prud'homme 2015). Urea used in agriculture is either supplied from urine in the manure slurry of livestock animals or produced synthetically. When comparing the two sources of urea, some studies have found that synthetic urea fertilizers have an immediate positive impact on crop yield and crop N-content (Khodaei Joghan et al. 2012; Paul and Beauchamp 1993; Salomonsson et al. 1994). However, manure slurry has been found to have a residual positive effect on crops in the years following application (Bhogal et al. 2016; Gutser et al. 2005; Paul and Beauchamp 1993; Schröder et al. 2006; Whitmore and Schroder 1996). Regarding ammonia emission, neither source of urea seems to present an advantage relative to the other after field application (Bouwman et al. 2002). However, in contrast to synthetic urea fertilizer, manure slurry will emit ammonia before it is applied to the field (e.g., from animal housing, storage tanks and handling). The formation of ammonia in the manure slurry is caused by urease-producing bacteria from livestock feces. Meanwhile, urea in synthetic fertilizers does not come into contact with urease until it is applied to the field. Without urease, the degradation of urea is so slow that it is negligible. For this reason, urease is found in a large variety of organisms, including plants, allowing them to directly utilize urea as a $\mathrm{N}$ source. The problem arises when urease hydrolyzes urea faster than the organisms can take up the ammonia, which consequently leads to ammonia emission. In addition to creating a loss of valuable fertilizer for the farmer, ammonia emission can lead to several problems from an environmental point of view. For this reason, international regulations have been implemented to reduce the emission of ammonia, the most recent being the NEC Directive 2016/2284/EC for EU member states (European Parliament 2016). To comply with these regulations, new ammonia mitigation technologies need to be implemented in the agricultural sector. Currently, the use of urease inhibitors in agriculture is still limited, although NBPT is seeing increased use as a stabilizing additive in urea-based synthetic fertilizers. To our knowledge, treatment of animal manure slurry with urease inhibitors has not yet been commercialized. The reasons for the lack of adoption in livestock production are likely the limited chemical stability of the inhibitors (e.g., NBPT and PPDA), the need for reapplication, the lack of efficient and automated application systems, and a subsequent increase in the cost for the farmer (Kai 2013; McCrory and Hobbs 2001; Varel 1997; Youngdahl et al. 1986). Additional studies on the effects (N-retention, crop yield, etc.) as well as the environmental impact of urease inhibitors are still needed. Continuous research in the fields of ammonia emission mitigation technologies and the microbial and biochemical aspects of ureolytic bacteria in soil and animal feces may lead to more advanced biotechnological solutions to reduce ammonia emissions from agriculture. If urease inhibitors, which are stable and effective under conditions typically found in the manure slurry and on fields, can be identified, they offer a relatively simple approach to keep nitrogen in the stable and non-volatile urea form until the crops are able to utilize it. One big challenge will be to make such a technology cost-effective; however, with new and stricter regulations on ammonia emission, it will only become more important to identify novel strategies for controlling ammonia volatilization.

Acknowledgements This work was supported by a Grant (ManUREA Technology; File Number 34009-15-0934) from the Green Development Programme, GUDP, under The Danish Ministry of Environment and Food.

Open Access This article is distributed under the terms of the Creative Commons Attribution 4.0 International License (http:// creativecommons.org/licenses/by/4.0/), which permits unrestricted use, distribution, and reproduction in any medium, provided you give appropriate credit to the original author(s) and the source, provide a link to the Creative Commons license, and indicate if changes were made.

\section{References}

Abdel Monem M, Lindsay WL, Sommer R, Ryan J (2009) Loss of nitrogen from urea applied to rainfed wheat in varying rainfall zones in northern Syria. Nutr Cycl Agroecosyst 86:357-366. https://doi.org/10.1007/s10705-009-9297-0

Aerts R, Berendse F, Decaluwe H, Schmitz M (1990) Competition in heathland along an experimental gradient of nutrient availability. Oikos 57:310-318. https://doi.org/10. 2307/3565959

Alderighi L, Gans P, Ienco A, Peters D, Sabatini A, Vacca A (1999) Hyperquad simulation and speciation (HySS): a utility program for the investigation of equilibria involving 
soluble and partially soluble species. Coord Chem Rev 184:311-318. https://doi.org/10.1016/S0010-8545(98)00 260-4

Ambrose JF, Kistiakowsky GB, Kridl AG (1951) Inhibition of urease by silver ions. J Am Chem Soc 73:1232-1236. https://doi.org/10.1021/ja01147a106

Anderson N, Strader R, Davidson C (2003) Airborne reduced nitrogen: ammonia emissions from agriculture and other sources. Environ Int 29:277-286. https://doi.org/10.1016/ S0160-4120(02)00186-1

Andersson M (1998) Reducing ammonia emissions by cooling of manure in manure culverts. Nutr Cycl Agroecosyst 51:73-79. https://doi.org/10.1023/A:1009755311356

Aneja VP, Schlesinger WH, Erisman JW (2009) Effects of agriculture upon the air quality and climate: research, policy, and regulations. Environ Sci Technol 43:4234-4240. https://doi.org/10.1021/es8024403

Arrigo KR (2005) Marine microorganisms and global nutrient cycles. Nature 437:349-355. https://doi.org/10.1038/ nature 04158

Artola E et al (2011) Effect of N-(n-butyl) thiophosphoric triamide on urea metabolism and the assimilation of ammonium by Triticum aestivum L. Plant Growth Regul 63:73-79. https://doi.org/10.1007/s10725-010-9513-6

Banerjee MR, Burton DL, Grant CA (1999) Influence of urea fertilization and urease inhibitor on the size and activity of the soil microbial biomass under conventional and zero tillage at two sites. Can J Soil Sci 79:255-263. https://doi. org/10.4141/S97-049

Barrington SF, Moreno RC (1995) Swine manure nitrogen conservation in storage using sphagnum moss. J Environ Qual 24:603-607. https://doi.org/10.2134/jeq1995. $00472425002400040008 x$

Behera SN, Sharma M, Aneja VP, Balasubramanian R (2013) Ammonia in the atmosphere: a review on emission sources, atmospheric chemistry and deposition on terrestrial bodies. Environ Sci Pollut Res Int 20:8092-8131. https://doi.org/ 10.1007/s11356-013-2051-9

Bekheet IA, Syrett PJ (1977) Urea-degrading enzymes in algae. $\mathrm{Br}$ Phycol J 12:137-143. https://doi.org/10.1080/ 00071617700650151

Benini S, Rypniewski WR, Wilson KS, Miletti S, Ciurli S, Mangani S (1999) A new proposal for urease mechanism based on the crystal structures of the native and inhibited enzyme from Bacillus pasteurii: why urea hydrolysis costs two nickels. Structure 7:205-216. https://doi.org/10.1016/ s0969-2126(99)80026-4

Bhogal A, Williams JR, Nicholson FA, Chadwick DR, Chambers KH, Chambers BJ (2016) Mineralization of organic nitrogen from farm manure applications. Soil Use Manag 32:32-43. https://doi.org/10.1111/sum.12263

Booth JL, Vishniac HS (1987) Urease testing and yeast taxonomy. Can J Microbiol 33:396-404. https://doi.org/10. 1139/m87-069

Bosch C, Meiser W (1922) Process of manufacturing urea. U.S. Patent, 1,429,483

Bouwman AF, Boumans LJM, Batjes NH (2002) Estimation of global $\mathrm{NH}_{3}$ volatilization loss from synthetic fertilizers and animal manure applied to arable lands and grasslands. Glob Biogeochem Cycl 16:8-13. https://doi.org/10.1029/ 2000GB001389
Breitenbach JM, Hausinger RP (1988) Proteus mirabilis urease. Partial purification and inhibition by boric acid and boronic acids. Biochem J 250:917-920. https://doi.org/10.1042/ bj2500917

Burbank MB, Weaver TJ, Williams BC, Crawford RL (2012) Urease activity of ureolytic bacteria isolated from six soils in which calcite was precipitated by indigenous bacteria. Geomicrobiol J 29:389-395. https://doi.org/10.1080/ 01490451.2011.575913

Bussink DW, Oenema O (1998) Ammonia volatilization from dairy farming systems in temperate areas: a review. Nutr Cycl Agroecosyst 51:19-33. https://doi.org/10.1023/A: 1009747109538

Cai GX, Freney JR, Muirhead WA, Simpson JR, Chen DL, Trevitt ACF (1989) The evaluation of urease inhibitors to improve the efficiency of urea as a $\mathrm{N}$-source for flooded rice. Soil Biol Biochem 21:137-145. https://doi.org/10. 1016/0038-0717(89)90023-0

Callahan BP, Yuan Y, Wolfenden R (2005) The burden borne by urease. J Am Chem Soc 127:10828-10829. https://doi.org/ 10.1021/ja0525399

Camargo JA, Alonso A (2006) Ecological and toxicological effects of inorganic nitrogen pollution in aquatic ecosystems: a global assessment. Environ Int 32:831-849. https:// doi.org/10.1016/j.envint.2006.05.002

Canh TT, Verstegen MW, Aarnink AJ, Schrama JW (1997) Influence of dietary factors on nitrogen partitioning and composition of urine and feces of fattening pigs. J Anim Sci 75:700-706

Carozzi M, Ferrara RM, Rana G, Acutis M (2013) Evaluation of mitigation strategies to reduce ammonia losses from slurry fertilisation on arable lands. Sci Total Environ 449:126-133. https://doi.org/10.1016/j.scitotenv.2012.12. 082

Chang DI, Lee SJ, Choi WY (2004) A pilot-scale biofilter system to reduce odor from swine operation. In: ASAE annual meeting, St. Joseph. Paper number 044056. https://doi.org/ 10.13031/2013.16769

Choi W-J, Chang SX, Kwak J-H, Jung J-W, Lim S-S, Yoon K-S, Choi S-M (2007) Nitrogen transformations and ammonia volatilization losses from $15 \mathrm{~N}$-urea as affected by the coapplication of composted pig manure. Can J Soil Sci 87:485-493. https://doi.org/10.4141/cjss07002

Ciurli S, Marzadori C, Benini S, Deiana S, Gessa C (1996) Urease from the soil bacterium Bacillus pasteurii: immobilization on Ca-polygalacturonate. Soil Biol Biochem 28:811-817. https://doi.org/10.1016/0038-0717(96)000 $20-\mathrm{X}$

Cook AR (1976) Urease activity in the rumen of sheep and the isolation of ureolytic bacteria. J Gen Microbiol 92:32-48. https://doi.org/10.1099/00221287-92-1-32

Creason GL, Schmitt MR, Douglass EA, Hendrickson LL (1990) Urease inhibitory activity associated with N-(nbutyl)thiophosphoric triamide is due to formation of its oxon analog. Soil Biol Biochem 22:209-211. https://doi. org/10.1016/0038-0717(90)90088-H

Dai X, Karring H (2014) A determination and comparison of urease activity in feces and fresh manure from pig and cattle in relation to ammonia production and $\mathrm{pH}$ changes. PLoS ONE 9:e110402. https://doi.org/10.1371/journal. pone.0110402 
Dancer WS, Peterson LA, Chesters G (1973) Ammonification and nitrification of $\mathrm{N}$ as influenced by soil $\mathrm{Ph}$ and previous $\mathrm{N}$ treatments. Soil Sci Soc Am J 37:67-69. https://doi.org/ 10.2136/sssaj1973.03615995003700010024x

Dixon NE, Riddles PW, Gazzola C, Blakeley RL, Zerner B (1980) Jack bean urease (EC 3.5.1.5). V. On the mechanism of action of urease on urea, formamide, acetamide, $\mathrm{N}$-methylurea, and related compounds. Can J Biochem 58:1335-1344

Dynowski M, Mayer M, Moran O, Ludewig U (2008) Molecular determinants of ammonia and urea conductance in plant aquaporin homologs. FEBS Lett 582:2458-2462. https:// doi.org/10.1016/j.febslet.2008.06.012

Edouard N, Hassouna M, Robin P, Faverdin P (2016) Low degradable protein supply to increase nitrogen efficiency in lactating dairy cows and reduce environmental impacts at barn level. Animal 10:212-220. https://doi.org/10.1017/ S1751731115002050

EEA (2017) National Emission Ceilings Directive emissions data viewer. European Environment Agency. https://www. eea.europa.eu/ds_resolveuid/ 797cd54b97ac475a9b53acad3ca0f2ac. Accessed 18 July 2017

Eitinger T, Mandrand-Berthelot MA (2000) Nickel transport systems in microorganisms. Arch Microbiol 173:1-9. https://doi.org/10.1007/s002030050001

Engel RE, Towey BD, Gravens E (2015) Degradation of the urease inhibitor NBPT as affected by soil $\mathrm{pH}$. Soil Sci Soc Am J 79:1674-1683. https://doi.org/10.2136/sssaj2015.05. 0169

Erisman JW, Bleeker A, Galloway J, Sutton MS (2007) Reduced nitrogen in ecology and the environment. Environ Pollut 150:140-149. https://doi.org/10.1016/j.envpol.2007.06. 033

Estiu G, Merz KM Jr (2004) The hydrolysis of urea and the proficiency of urease. J Am Chem Soc 126:6932-6944. https://doi.org/10.1021/ja049327g

European Parliament CoEU (2016) Directive (EU) 2016/2284 of the European Parliament and of the Council of 14 December 2016 on the reduction of national emissions of certain atmospheric pollutants, amending Directive 2003/35/EC and repealing Directive 2001/81/EC. European Union

European Parliament CotEU (2001) Directive 2001/81/EC of the European Parliament and of the Council of 23 October 2001 on national emission ceilings for certain atmospheric pollutants. European Parliament, Council of the European Union, OJ L 309, 27-11-2001

Fangmeier A, Hadwiger-Fangmeier A, Van der Eerden L, Jager HJ (1994) Effects of atmospheric ammonia on vegetation: a review. Environ Pollut 86:43-82

FAO (2015) World fertilizer trends and outlook to 2018. Food and Agriculture Organization of the United Nations. http:// www.fao.org/documents/card/en/c/db95327a-5936-4d01b67d-7e55e532e8f5/. Accessed 19 Jan 2018

Fenn ME et al (1998) Nitrogen excess in North American ecosystems: predisposing factors, ecosystem responses, and management strategies. Ecol Appl 8:706-733. https:// doi.org/10.2307/2641261

Font M et al (2008) Structural characteristics of phosphoramide derivatives as urease inhibitors. Requirements for activity.
J Agric Food Chem 56:8451-8460. https://doi.org/10. 1021/jf801786d

Forrestal PJ et al (2016) Ammonia emissions from urea, stabilized urea and calcium ammonium nitrate: insights into loss abatement in temperate grassland. Soil Use Manag 32:92-100. https://doi.org/10.1111/sum.12232

Fowler D et al (2015) Effects of global change during the 21st century on the nitrogen cycle. Atmos Chem Phys 15:13849-13893. https://doi.org/10.5194/acp-15-138492015

Frankenberger WT, Tabatabai MA (1982) Amidase and urease activities in plants. Plant Soil 64:153-166. https://doi.org/ 10.1007/Bf02184247

Funk TL, Hussey R, Zhang Y, Ellis M (2004) Synthetic covers for emissions control from earthen embanked swine lagoons_-part I: positive pressure lagoon cover. Appl Eng Agric 20:233-238. https://doi.org/10.13031/2013.15889

Gale GR (1965) Inhibition of urease by hydroxyurea. Biochem Pharmacol 14:693-698. https://doi.org/10.1016/00062952(65)90086-9

Gerendas J, Zhu Z, Sattelmacher B (1998) Influence of N and Ni supply on nitrogen metabolism and urease activity in rice (Oryza sativa L.). J Exp Bot 49:1545-1554. https://doi.org/ 10.1093/jexbot/49.326.1545

Girvan MS, Bullimore J, Pretty JN, Osborn AM, Ball AS (2003) Soil type is the primary determinant of the composition of the total and active bacterial communities in arable soils. Appl Environ Microb 69:1800-1809. https://doi.org/10. 1128/Aem.69.3.1800-1809.2003

Goldraij A, Beamer LJ, Polacco JC (2003) Interallelic complementation at the ubiquitous urease coding locus of soybean. Plant Physiol 132:1801-1810. https://doi.org/10. 1104/pp.103.022699

Groot Koerkamp PWG et al (1998) Concentrations and emissions of ammonia in livestock buildings in northern Europe. J Agric Eng Res 70:79-95. https://doi.org/10.1006/ jaer.1998.0275

Gutser R, Ebertseder T, Weber A, Schraml M, Schmidhalter U (2005) Short-term and residual availability of nitrogen after long-term application of organic fertilizers on arable land. J Plant Nutr Soil Sci 168:439-446. https://doi.org/10. 1002/jpln.200520510

Ha NC, Oh ST, Sung JY, Cha KA, Lee MH, Oh BH (2001) Supramolecular assembly and acid resistance of Helicobacter pylori urease. Nat Struct Biol 8:505-509. https:// doi.org/10.1038/88563

Hamm AC, Tenuta M, Krause DO, Ominski KH, Tkachuk VL, Flaten DN (2016) Bacterial communities of an agricultural soil amended with solid pig and dairy manures, and urea fertilizer. Appl Soil Ecol 103:61-71. https://doi.org/10. 1016/j.apsoil.2016.02.015

Hanlon DP (1975) The distribution of arginase and urease in marine invertebrates. Comp Biochem Physiol B 52:261-264

Heffer P, Prud'homme M (2015) Fertilizer outlook 2015-2019. In: 83rd IFA annual conference, Istanbul

Hendrickson LL, Douglass EA (1993) Metabolism of the urease inhibitor N-(n-butyl)thiophosphoric triamide (NBPT) in soils. Soil Biol Biochem 25:1613-1618. https://doi.org/10. 1016/0038-0717(93)90017-6 
Hill RW, Wyse GA, Anderson M (2008) Kidneys and excretion (with notes on nitrogen excretion). In: Animal physiology, 2nd edn. Sinauer Associates Inc., Sunderland, pp 715-749

Hristov AN (2011) Technical note: Contribution of ammonia emitted from livestock to atmospheric fine particulate matter (PM2.5) in the United States. J Dairy Sci 94:3130-3136. https://doi.org/10.3168/jds.2010-3681

Huijsmans JFM, Hol JMG, Hendriks MMW (2001) Effect of application technique, manure characteristics, weather and field conditions on ammonia volatilization from manure applied to grassland. Neth J Agric Sci 49:323-342. https:// doi.org/10.1016/S1573-5214(01)80021-X

Huijsmans JFM, Hol JMG, Vermeulen GD (2003) Effect of application method, manure characteristics, weather and field conditions on ammonia volatilization from manure applied to arable land. Atmos Environ 37:3669-3680. https://doi.org/10.1016/S1352-2310(03)00450-3

Hutchings NJ, Sommer SG, Andersen JM, Asman WAH (2001) A detailed ammonia emission inventory for Denmark. Atmos Environ 35:1959-1968. https://doi.org/10.1016/ S1352-2310(00)00542-2

Jabri E, Carr MB, Hausinger RP, Karplus PA (1995) The crystal structure of urease from Klebsiella aerogenes. Science 268:998-1004. https://doi.org/10.1126/science.7754395

Jensen A $\varnothing$ (2002) Changing the environment in swine buildings using sulfuric acid. Trans ASAE 45:223-227. https://doi. org/10.13031/2013.7874

Kai P (2013) Screening af Additiver: Reduktion af ammoniakfordampning fra gulvoverflader i kvægstalde. http://innomt.dk/

Kai P, Pedersen P, Jensen JE, Hansen MN, Sommer SG (2008) A whole-farm assessment of the efficacy of slurry acidification in reducing ammonia emissions. Eur $\mathrm{J}$ Agron 28:148-154. https://doi.org/10.1016/j.eja.2007.06.004

Khodaei Joghan A, Ghalavand A, Aghaalikhani M, Gholamhoseini M, Dolatabadian A (2012) How organic and chemical nitrogen fertilizers, zeolite, and combinations influence wheat yield and grain mineral content. J Crop Improv 26:116-129. https://doi.org/10.1080/15427528. 2011.616985

Klose S, Tabatabai MA (1999) Urease activity of microbial biomass in soils. Soil Biol Biochem 31:205-211. https:// doi.org/10.1016/S0038-0717(98)00090-X

Kot M, Zaborska W, Orlinska K (2001) Inhibition of jack bean urease by $\mathrm{N}$-(n-butyl) thiophosphorictriamide and $\mathrm{N}-(\mathrm{n}-$ butyl) phosphorictriamide: determination of the inhibition mechanism. J Enzyme Inhib 16:507-516. https://doi.org/ $10.1080 / 14756360127569$

Krajewska B (2009) Ureases I. Functional, catalytic and kinetic properties: a review. J Mol Catal B Enzym 59:9-21. https:// doi.org/10.1016/j.molcatb.2009.01.003

Krupa SV (2003) Effects of atmospheric ammonia $\left(\mathrm{NH}_{3}\right)$ on terrestrial vegetation: a review. Environ Pollut 124:179-221. https://doi.org/10.1016/S0269-7491(02)00434-7

Kulling DR, Menzi H, Krober TF, Neftel A, Sutter F, Lischer P, Kreuzer M (2001) Emissions of ammonia, nitrous oxide and methane from different types of dairy manure during storage as affected by dietary protein content. J Agric Sci 137:235-250
Kumar S, Kayastha AM (2010a) Acetohydroxamic acid-a competitive inhibitor of urease from soybean (glycine max). Med Chem Res 19:S113-S114

Kumar S, Kayastha AM (2010b) Inhibition studies of soybean (glycine max) urease with heavy metals, sodium salts of mineral acids, boric acid, and boronic acids. J Enzyme Inhib Med Chem 25:646-652. https://doi.org/10.3109/ 14756360903468155

Laidler KJ, Hoare JP (1950) The molecular kinetics of the ureaurease system. III. Heats and entropies of complex formation and reaction. J Am Chem Soc 72:2489-2494

Larson AD, Kallio RE (1954) Purification and properties of bacterial urease. J Bacteriol 68:67-73

Li M, Cheng XH, Guo HX (2013) Heavy metal removal by biomineralization of urease producing bacteria isolated from soil. Int Biodeterior Biodegrad 76:81-85. https://doi. org/10.1016/j.ibiod.2012.06.016

$\mathrm{Li} \mathrm{J}$ et al (2014) Use of nitrogen process inhibitors for reducing gaseous nitrogen losses from land-applied farm effluents. Biol Fertil Soils 50:133-145. https://doi.org/10.1007/ s00374-013-0842-2

Liu LH, Ludewig U, Frommer WB, von Wiren N (2003a) AtDUR3 encodes a new type of high-affinity urea/H+ symporter in Arabidopsis. Plant Cell 15:790-800. https:// doi.org/10.1105/tpc.007120

Liu LH, Ludewig U, Gassert B, Frommer WB, von Wiren N (2003b) Urea transport by nitrogen-regulated tonoplast intrinsic proteins in Arabidopsis. Plant Physiol 133:1220-1228. https://doi.org/10.1104/pp.103.027409

Liu F, Fiencke C, Guo J, Rieth R, Dong R, Pfeiffer EM (2017) Performance evaluation and optimization of field-scale bioscrubbers for intensive pig house exhaust air treatment in northern Germany. Sci Total Environ 579:694-701. https://doi.org/10.1016/j.scitotenv.2016.11.039

Lloyd AB, Sheaffe MJ (1973) Urease activity in soils. Plant Soil 39:71-80. https://doi.org/10.1007/bf00018046

Mackerras AH, Smith GD (1986) Urease activity of the cyanobacterium anabaena-cylindrica. J Gen Microbiol 132:2749-2752

Marchesan E, Grohs M, Walter M, da Silva LS, Formentini TC (2013) Agronomic performance of rice to the use of urease inhibitor in two cropping systems. Rev Cienc Agron 44:594-603

Massey RE, Zulovich JE, Lory JA, Millmier AM (2003) Farm level economic impacts of owning and operating impermeable lagoon covers. In: Air pollution from agricultural operations III conference, North Carolina, pp 346-353

Matsushima M, Lim SS, Kwak JH, Park HJ, Lee SI, Lee DS, Choi WJ (2009) Interactive effects of synthetic nitrogen fertilizer and composted manure on ammonia volatilization from soils. Plant Soil 325:187-196. https://doi.org/10. 1007/s11104-009-9967-3

Mazzei L, Cianci M, Contaldo U, Musiani F, Ciurli S (2017) Urease inhibition in the presence of $\mathrm{N}$-(n-Butyl)thiophosphoric triamide, a suicide substrate: structure and kinetics. Biochemistry 56:5391-5404. https://doi.org/10.1021/acs. biochem.7b00750

McCrory DF, Hobbs PJ (2001) Additives to reduce ammonia and odor emissions from livestock wastes: a review. J Environ Qual 30:345-355 
McGinn SM, Sommer SG (2007) Ammonia emissions from land-applied beef cattle manure. Can J Soil Sci. https://doi. org/10.4141/S06-053

Melse RW, Ogink NWM (2005) Air scrubbing techniques for ammonia and odor reduction at livestock operations: review of on-farm research in the Netherlands. Trans ASAE 48:2303-2313. https://doi.org/10.13031/2013. 20094

Meyer-Bothling LE, Polacco JC (1987) Mutational analysis of the embryo-specific urease locus of soybean. Mol Gen Genet 209:439-444. https://doi.org/10.1007/BF00331147

Miljøstyrelsen (2015) List of environmental technologies. Ministry of Environment and Food. http://eng.mst.dk/ trade/agriculture/environmental-technologies-forlivestock-holdings/air-cleaning/. Accessed 13 Feb 2018

Misselbrook T, Hunt J, Perazzolo F, Provolo G (2016) Greenhouse gas and ammonia emissions from slurry storage: impacts of temperature and potential mitigation through covering (pig slurry) or acidification (cattle slurry). J Environ Qual 45:1520-1530. https://doi.org/10.2134/ jeq2015.12.0618

Mobley HL, Hausinger RP (1989) Microbial ureases: significance, regulation, and molecular characterization. Microbiol Rev 53:85-108

Mobley HL, Island MD, Hausinger RP (1995) Molecular biology of microbial ureases. Microbiol Rev 59:451-480

Munoz A, Raso MJ, Pineda M, Piedras P (2006) Degradation of ureidoglycolate in French bean (Phaseolus vulgaris) is catalysed by a ubiquitous ureidoglycolate urea-lyase. Planta 224:175-184. https://doi.org/10.1007/s00425-0050186-8

Musiani F, Arnofi E, Casadio R, Ciurli S (2001) Structure-based computational study of the catalytic and inhibition mechanisms of urease. J Biol Inorg Chem 6:300-314. https://doi. org/10.1007/s007750000204

Myrold DD (2003) Soil nitrogen cycle. In: Encyclopedia of environmental microbiology, Wiley. https://doi.org/10. 1002/0471263397.env149

Navarro C, Wu LF, Mandrand-Berthelot MA (1993) The nik operon of Escherichia coli encodes a periplasmic bindingprotein-dependent transport system for nickel. Mol Microbiol 9:1181-1191

Nelson MB, Martiny AC, Martiny JB (2016) Global biogeography of microbial nitrogen-cycling traits in soil. Proc Natl Acad Sci USA 113:8033-8040. https://doi.org/10.1073/ pnas. 1601070113

Paul JW, Beauchamp EG (1993) Nitrogen availability for corn in soils amended with urea, cattle slurry, and solid and composted manures. Can J Soil Sci 73:253-266. https:// doi.org/10.4141/cjss93-027

Pearson J, Stewart GR (1993) The deposition of atmospheric ammonia and its effects on plants. New Phytol 125:283-305. https://doi.org/10.1111/j.1469-8137.1993. tb03882.x

Pedersen P (2005) Linespilsanlæg med køling i drægtighedsstalde. Landsudvalget for svin, videncenter for svineproduktion, den rullende afprøvning. http://svineproduktion. dk/. Accessed 13 Feb 2018

Pettit NM, Smith ARJ, Freedman RB, Burns RG (1976) Soil urease: activity, stability and kinetic properties. Soil Biol Biochem 8:479-484
Polacco JC, Winkler RG (1984) Soybean leaf urease: a seed enzyme? Plant Physiol 74:800-803

Portejoie S, Martinez J, Guiziou F, Coste CM (2003) Effect of covering pig slurry stores on the ammonia emission processes. Bioresour Technol 87:199-207. https://doi.org/10. 1016/S0960-8524(02)00260-2

Prober SM et al (2015) Plant diversity predicts beta but not alpha diversity of soil microbes across grasslands worldwide. Ecol Lett 18:85-95. https://doi.org/10.1111/ele.12381

Qin SP, Hu CS, Wang YY, Li XX, He XH (2010) Tillage effects on intracellular and extracellular soil urease activities determined by an improved chloroform fumigation method. Soil Sci 175:568-572. https://doi.org/10.1097/SS. 0b013e3181fa2810

Reddy KRC, Kayastha AM (2006) Boric acid and boronic acids inhibition of pigeonpea urease. J Enzyme Inhib Med Chem 21:467-470

Reinbothe H, Mothes K (1962) Urea, ureides, and guanidines in plants. Annu Rev Plant Physiol 13:129. https://doi.org/10. 1146/annurev.pp.13.060162.001021

Riva DR et al (2011) Low dose of fine particulate matter (PM2.5) can induce acute oxidative stress, inflammation and pulmonary impairment in healthy mice. Inhal Toxicol 23:257-267. https://doi.org/10.3109/08958378.2011.566290

Rochette P, Angers DA, Chantigny MH, MacDonald JD, Gasser MO, Bertrand N (2009) Reducing ammonia volatilization in a no-till soil by incorporating urea and pig slurry in shallow bands. Nutr Cycl Agroecosyst 84:71-80. https:// doi.org/10.1007/s10705-008-9227-6

Salazar F, Martinez-Lagos J, Alfaro M, Misselbrook T (2014) Ammonia emission from a permanent grassland on volcanic soil after the treatment with dairy slurry and urea. Atmos Environ 95:591-597. https://doi.org/10.1016/j. atmosenv.2014.06.057

Salomonsson L, Jonsson A, Salomonsson AC, Nilsson G (1994) Effects of organic fertilizers and urea when applied to spring wheat. Acta Agric Scand B Plant Soil Sci 44:170-178. https://doi.org/10.1080/09064719409410241

Schafer UK, Kaltwasser H (1994) Urease from staphylococcussaprophyticus: purification, characterization and comparison to staphylococcus-xylosus urease. Arch Microbiol 161:393-399. https://doi.org/10.1007/Bf00288948

Schlesinger RB (2007) The health impact of common inorganic components of fine particulate matter (PM2.5) in ambient air: a critical review. Inhal Toxicol 19:811-832. https://doi. org/10.1080/08958370701402382

Schneider J, Kaltwasser H (1984) Urease from Arthrobacteroxydans, a nickel-containing enzyme. Arch Microbiol 139:355-360. https://doi.org/10.1007/Bf00408379

Schröder JJ, Jansen AG, Hilhorst GJ (2006) Long-term nitrogen supply from cattle slurry. Soil Use Manag 21:196-204. https://doi.org/10.1111/j.1475-2743.2005.tb00125.x

Scotford IM, Williams AG (2001) SE-structure and environment: practicalities, costs and effectiveness of a floating plastic cover to reduce ammonia emissions from a pig slurry lagoon. J Agric Eng Res 80:273-281. https://doi.org/ 10.1006/jaer.2001.0744

Sharma B, Ahlert RC (1977) Nitrification and nitrogen removal. Water Res 11:897-925. https://doi.org/10.1016/00431354(77)90078-1 
Shaw WHR, Bordeaux JJ (1955) The decomposition of urea in aqueous media. J Am Chem Soc 77:4729-4733. https://doi. org/10.1021/ja01623a011

Shaw WHR, Raval DN (1961) The inhibition of urease by methylurea. J Am Chem Soc 83:2866-2868. https://doi. org/10.1021/ja01474a019

Shi XZ, Hu HW, Kelly K, Chen DL, He JZ, Suter H (2017) Response of ammonia oxidizers and denitrifiers to repeated applications of a nitrification inhibitor and a urease inhibitor in two pasture soils. J Soil Sediment 17:974-984. https://doi.org/10.1007/s11368-016-1588-x

Silva AGB, Sequeira CH, Sermarini RA, Otto R (2017) Urease inhibitor NBPT on ammonia volatilization and crop productivity: a meta-analysis. Agron J 109:1-13. https://doi. org/10.2134/agronj2016.04.0200

Silver S, Phung LT (1996) Bacterial heavy metal resistance: new surprises. Annu Rev Microbiol 50:753-789. https:// doi.org/10.1146/annurev.micro.50.1.753

Singh J, Kunhikrishnan A, Bolan NS, Saggar S (2013) Impact of urease inhibitor on ammonia and nitrous oxide emissions from temperate pasture soil cores receiving urea fertilizer and cattle urine. Sci Total Environ 465:56-63. https://doi. org/10.1016/j.scitotenv.2013.02.018

Smith VH (2003) Eutrophication of freshwater and coastal marine ecosystems: a global problem. Environ Sci Pollut Res Int 10:126-139. https://doi.org/10.1065/espr2002.12. 142

Sommer SG, Hutchings NJ (2001) Ammonia emission from field applied manure and its reduction: invited paper. Eur J Agron 15:1-15. https://doi.org/10.1016/S1161-0301(01) 00112-5

Sorensen M, Daneshvar B, Hansen M, Dragsted LO, Hertel O, Knudsen L, Loft S (2003) Personal PM2.5 exposure and markers of oxidative stress in blood. Environ Health Perspect 111:161-165. https://doi.org/10.1289/ehp.5646

Stebbins N, Holland MA, Cianzio SR, Polacco JC (1991) Genetic tests of the roles of the embryonic ureases of soybean. Plant Physiol 97:1004-1010

Stevens RJ, Laughlin RJ, Frost JP (1989) Effect of acidification with sulphuric acid on the volatilization of ammonia from cow and pig slurries. J Agric Sci 113:389-395. https://doi. org/10.1017/S0021859600070106

Sumner JB (1926) The isolation and crystallization of the enzyme urease preliminary paper. J Biol Chem 69:435-441

Suter H, Sultana H, Turner D, Davies R, Walker C, Chen DL (2013) Influence of urea fertiliser formulation, urease inhibitor and season on ammonia loss from ryegrass. Nutr Cycl Agroecosyst 95:175-185. https://doi.org/10.1007/ s10705-013-9556-y

Sutton MA, Oenema O, Erisman JW, Leip A, van Grinsven H, Winiwarter W (2011) Too much of a good thing. Nature 472:159-161. https://doi.org/10.1038/472159a

Swierstra D, Braam CR, Smits MC (2001) Grooved floor system for cattle housing: ammonia emission reduction and good slip resistance. Appl Eng Agric 17:85-90. https://doi.org/ 10.13031/2013.1929

Tedersoo L et al (2014) Fungal biogeography. Global diversity and geography of soil fungi. Science 346:125. https://doi. org/10.1126/science. 1256688 ten Hoeve M, Nyord T, Peters GM, Hutchings NJ, Jensen LS, Bruun S (2016) A life cycle perspective of slurry acidification strategies under different nitrogen regulations. J Clean Prod 127:591-599. https://doi.org/10.1016/j. jclepro.2016.04.014

Todd CD, Polacco JC (2004) Soybean cultivars 'Williams 82' and 'Maple Arrow' produce both urea and ammonia during ureide degradation. J Exp Bot 55:867-877. https://doi.org/ $10.1093 / \mathrm{jxb} / \mathrm{erh} 100$

UNECE (1999) Protocol to abate acidification, eutrophication and ground-level ozone. United Nations Economic Commission for Europe. http://www.unece.org/env/lrtap/ multi_h1.html. Accessed 19 Jan 2018

van der Eerden LJM (1982) Toxicity of ammonia to plants. Agric Environ 7:223-235. https://doi.org/10.1016/03041131(82)90015-7

van der Eerden LJM, de Visser PHB, van Dijk CJ (1998) Risk of damage to crops in the direct neighbourhood of ammonia sources. Environ Pollut 102:49-53. https://doi.org/10. 1016/s0269-7491(98)80014-6

Varel VH (1997) Use of urease inhibitors to control nitrogen loss from livestock waste. Bioresour Technol 62:11-17

Vitousek PM et al (1997) Technical report: Human alteration of the global nitrogen cycle: sources and consequences. Ecol Appl 7:737. https://doi.org/10.2307/2269431

Watson CJ, Miller H (1996) Short-term effects of urea amended with the urease inhibitor $\mathrm{N}$-(n-butyl) thiophosphoric triamide on perennial ryegrass. Plant Soil 184:33-45. https:// doi.org/10.1007/Bf00029272

Whitmore AP, Schroder JJ (1996) Modelling the change in soil organic $\mathrm{C}$ and $\mathrm{N}$ and the mineralization of $\mathrm{N}$ from soil in response to applications of slurry manure. Plant Soil 184:185-194. https://doi.org/10.1007/Bf00010448

Wu LF, Mandrand-Berthelot MA (1986) Genetic and physiological characterization of new Escherichia coli mutants impaired in hydrogenase activity. Biochimie 68:167-179. https://doi.org/10.1016/S0300-9084(86)81081-1

Xi R, Long XE, Huang S, Yao H (2017) pH rather than nitrification and urease inhibitors determines the community of ammonia oxidizers in a vegetable soil. AMB Express 7:129. https://doi.org/10.1186/s13568-017-0426-x

Youngdahl LJ, Lupin MS, Craswell ET (1986) New developments in nitrogen fertilizers for rice. Fertil Res 9:149-160. https://doi.org/10.1007/Bf01048700

Zanin L, Venuti S, Tomasi N, Zamboni A, De Brito Francisco RM, Varanini Z, Pinton R (2016) Short-term treatment with the urease inhibitor $\mathrm{N}$-(n-butyl) thiophosphoric triamide (NBPT) alters urea assimilation and modulates transcriptional profiles of genes involved in primary and secondary metabolism in maize seedlings. Front Plant Sci 7:845. https://doi.org/10.3389/fpls.2016.00845

Zantua MI, Bremner JM (1977) Stability of urease in soils. Soil Biol Biochem 9:135-140. https://doi.org/10.1016/00380717(77)90050-5

Zimmer M (2000) Molecular mechanics evaluation of the proposed mechanisms for the degradation of urea by urease. J Biomol Struct Dyn 17:787-797. https://doi.org/10.1080/ 07391102.2000.10506568 